\title{
Postmoderni postupci, istorija i fikcija u romanu Nacistička književnost u Americi Roberta Bolanja
}

\author{
Ana Z. Huber* \\ Univerzitet u Beogradu, Filološki fakultet
}

Ključne reči:
Nacistička književnost
u Americi
Roberto Bolanjo
postmoderna
istorija
fikcija

www.anali.fil.bg.ac.rs

\section{Apstrakt}

Tema ovog rada jeste upotreba postmodernih književnih postupaka u romanu Nacistička književnost u Americi (1996) čileanskog pisca Roberta Bolanja, kao i odnos istorije i fikcije u pomenutom delu. Oslanjajući se na ključne postavke književne postmoderne koje su formulisali Džon Bart, Čarls Dženks, Umberto Eko i Žan-Fransoa Liotar, kao i na induktivnu i deduktivnu metodu, ispitaćemo na koji način i u kojoj se meri Bolanjov roman formalno i sadržinski odlikuje postmodernom poetikom. Fokusiraćemo se na konkretne postmoderne postupke u romanu kao što su subjektivnost, intertekstualnost, referencijalnost, prisustvo ideologije, tehnika palimpsesta, ironija, parodija, dekonstrukcija, fragmentarnost i repetitivnost. Pokušaćemo da objasnimo kroz primere iz romana zašto je sam postupak pisanja ovog dela suštinski postmoderan. Pozvaćemo se i na formulaciju poetike postmodernizma Linde Hačion, pre svega po pitanju odnosa istorijskog i fikcionalnog u književnosti u doba postmoderne, kojim se dovode u pitanje nekada čvrste kategorije poput identiteta, autora, znanja, fikcije i stvarnosti. Pokazaćemo da spoj istorijske stvarnosti i fikcije predstavlja suštinu Bolanjove postmoderne poetike i da takvom poetikom čileanski autor briše granice između istorijskog i fikcionalnog. Bolanjo se poigrava istorijom, književnošću i naukom o književnosti. Prividno se udaljavajući od realnosti, ovaj književnik zapravo ukazuje na suštinske društveno-istorijske probleme Latinske Amerike. (примюено: 2. јула 2021; прихваћено: 15. септембра 2021) 


\section{Uvod}

Roberto Bolanjo (Roberto Bolaño, 1953-2003) jedan je od čuvenih predstavnika hispanoameričkog romana u razdoblju postbuma. Tipičan je književnik ovog doba zato što pokazuje spremnost da se bavi svakodnevicom kako bi ostvario pomak u egzistencijalnim teškoćama hispanoameričkog područja, kao i zbog eksperimentisanja sa narativnim tehnikama poput fragmentarnosti i parodije (Dickov, 2016: 238, 239).

Bolanjovo stvaralaštvo objedinjuje dve velike teme: književnost i politiku. Hačion $(1996: 18,141)$ smatra da je postmoderna neizbežno istorijska i politička i da predstavlja parodijski ili bar ironijski dijalog sa prošlošću, u kom postoji samosvest o društvenim i tekstualnim kontekstima u kojima diskursi funkcionišu. Obe ove odlike primetne su kod Bolanja. Specifičnost Bolanjovog pristupa pisanju o književnosti leži u tome što za njega književnost ne mora biti odraz civilizacije, kulture i prosvećenosti, već i divljaštva, varvarstva i naklonjenosti apsolutističkim i diktatorskim režimima. Političko nasilje pak može biti generisano pomoću državnog aparata, ali je njegov osnovni izvor izopačena ljudska psiha, i to najčešće psiha umetnika, kome diktatura postaje samo pogodna zaleđina. Romani u kojima se to najočitije primećuje jesu Treći rajh (El Tercer Reich, 1989), Nacistička književnost u Americi (La literatura nazi en América, 1996), Udaljena zvezda (Estrella distante, 1996) i Čileanski nokturno (Nocturno de Chile, 2000). Bolanjovi junaci su pisci ili bar pisci u pokušaju, književni kritičari i teoretičari, ljubitelji i poštovaoci književnosti, svi sa jasno iskazanim političkim stavovima. U sva četiri pomenuta romana, Bolanjo vešto prepliće temu umetničkog stvaralaštva sa turbulentnom stvarnošću Latinske Amerike u drugoj polovini XX veka, obeleženom diktaturama, vojnim pučevima, državnim udarima, političkim progonima i ubistvima i političkom emigracijom. Jedan od romana u kom je najočiglednija „veza između književnosti i politike“ ${ }^{\text {“ }}$ (Luche, 2013: 343) jeste Nacistička književnost u Americi, koja ujedno predstavlja „mapu koja sažima Bolanjova tematska i formalna interesovanja“2 (Sánchez Carbó, 2011: 146).

Bolanjova fikcija, kao i kod većine pisaca iz epohe postmoderne, zapravo je, u Bartovoj terminologiji „fikcija koja se sve više bavi sobom i sopstvenim procesima, a sve manje objektivnom stvarnošću i životom u svetu“3 (Barth, 1984: 200). Dok prvi deo tvrdnje apsolutno važi u Bolanjovom slučaju, drugi deo kod čileanskog autora doživljava nadgradnju. Naime, istražujući i predstavljajući proces stvaranja i sazrevanja umetnika i njihovih dela, Bolanjo spaja sferu imaginacije sa sferom realnosti i piše o političko-istorijskim okolnostima u postmodernom duhu reinterpretacije (Hačion, 1996: 75-76), odnosno uz ironijski otklon prema prošlosti (Eco, 1985: 67). Hačion (1996: 180) navodi da se u istoriografiji koriste tehnike fikcionalnog predstavljanja kako bi se stvorile imaginarne verzije stvarnih svetova, dok pisci postmodernih romana čine isto to, ali $i$ tome suprotno. Bolanjo je jedan od tih autora: on

1 "el nexo entre literatura y política". Svi prevodi u radu su autorski, osim kad je naznačeno drugačije.

2 "un mapa que condensa los intereses temáticos y formales de Bolańo"

3 "a fiction that is more and more about itself and its processes, less and less about objective reality and life in the world" 
koristi istoriografske tehnike, odnosno tehnike istorije književnosti, kako bi stvorio imaginarnu verziju sveta književnika ultradesničara.

Stvaralaštvo Roberta Bolanja proučavano je u svetlu postulata postmoderne (Rivera-Soto 2017; Rivera-Soto 2018; Sánchez Carbó 2011). U ovom radu, fokusiraćemo se na konkretne postmoderne elemente i postupke (subjektivnost, intertekstualnost, referencijalnost, prisustvo ideologije, tehnika palimpsesta, ironija, parodija, dekonstrukcija, fragmentarnost i repetitivnost ${ }^{4}$ ) u romanu Nacistička književnost $u$ Americi, kao i na odnos istorijske stvarnosti i fikcije u ovom delu. Pokušaćemo da objasnimo zašto je sam postupak pisanja ovog dela suštinski postmoderan. Oslonićemo se na teorijske postavke o postmoderni koje su formulisali Džon Bart, Čarls Dženks, Umberto Eko i Žan-Fransoa Liotar. Imaćemo u vidu formulaciju poetike postmodernizma Linde Hačion, koja se tiče odnosa istorijskog i fikcionalnog u književnosti u doba postmoderne.

\section{Bolanjo i postmoderni okviri}

Za hispanistiku je posebno značajno to što je pojam postmoderne prvi upotrebio španski pisac Federiko de Onis (Federico de Onís) 1934. godine u Antologiji španske i hispanoameričke književnosti (Antología de la poesía española e hispanoamericana) (Hasan, 1983: 16; Dženks, 2016: 8). To je pojam koji ujedno nastavlja i prevazilazi pojam modernizma; temelji se na novim tehnikama i na starim obrascima (Dženks, 2016: 15, 25). Bart kao jednu od ključnih odlika postmodernog pisanja navodi potrebu za posredovanjem između teksta i čitaoca. Naime, on tvrdi da su šezdesete i sedamdesete godine XX veka donele „procvat neophodne posvećeničke industrije tumača, beležnika, tragača za aluzijama, koji bi posredovali između teksta i čitaoca“5 (Barth, 1984: 201). Bolanjo se, poznajući postmoderne tendencije, odlučio da formu čija je svrha tumačenje književnosti iskoristi u svrhe predstavljanja jednog imaginarnog, fiktivnog sveta. Tako on u duhu postmoderne koristi postmoderno književno-naučno sredstvo čineći ga još "dodatno“ postmodernim time što mu daje fikcionalnu dimenziju. Kroz roman Nacistička književnost u Americi Bolanjo pokazuje značaj posredovanja između književnosti i čitalaca i daje sebi dvojaku ulogu: književnika i književnog tumača. Ovim se već otvara i pitanje nefiksiranosti identiteta, odnosno poigravanja ulogama i pripovedačkim pozicijama u okviru književnog dela.

Bart (Barth, 1984: 203) dalje navodi da je ideal postmoderne da se izdigne iznad „konflikta između realizma i irealizma, formalizma i opsesije sadržinom, čiste i angažovane književnosti, elitističke i treš proze“6. Bolanjo kroz svoje stvaralaštvo uspeva u tome?: on smešta imaginarne likove u realističan istorijski kontekst (Prvi

4 U pitanju su kategorije koje ističu Hačion (1996: 204) i Dženks (2016: 26).

5 "the engenderment of a necessary priestly industry of explicators, annotators, allusion-chasers, to mediate between the text and the reader"

6 "the quarrel between realism and irrealism, formalism and 'contentism', pure and committed literature, coterie fiction and junk fiction"

7 Bart (Barth, 1984: 204) ističe Gabrijela Garsiju Markesa kao primer uspešne sinteze navedenih elemenata. Mnogi hispanoamerički autori istaknuti su kao najbolji predstavnici postmoderne književnosti: Borhes (Hasan 1983; Dženks, 2016: 41), Kortasar (Hačion 1996; Hasan 1983), Garsija Markes (Hasan 1983). 
svetski rat, Meksička revolucija, Španski građanski rat, Drugi svetski rat, Aljendeov dolazak na vlast i Pinočeova diktatura, Sandinistički pokret, Malvinski rat) zajedno sa stvarnim ličnostima ${ }^{8}$ (Hose Antonio Primo de Rivera, Musolini, Staljin, Če Gevara, Fidel i Raul Kastro, Vagner, Dionisio Ridrueho, Espronseda, Garsija Lorka, Sor Huana Ines de la Krus, Alfonso Rejes, Borhes, Kortasar, Sabato, Leopoldo Marećal, Hose Lesama Lima, Virhilio Pinjera, Alfonsina Storni, Nikanor Para, Mark Tven, Dilan Tomas, Filip Dik, Ibzen, bitnici Ginzberg i Keruak ${ }^{9}$, Čarls Menson). Bolanjo vodi računa o izboru forme koju ispunjava pažljivo odabranom sadržinom, kroz čistu, virtuoznu književnost provlači angažovane elemente, a svojim likovima pripisuje delovanje u okviru elitističke, ali i treš literature. Likovi ulaze u međusobne interakcije (pisci Ignasio Subieta i Hesus Fernandes-Gomes su najbolji prijatelji sa Irmom Karasko, troje pisaca su članovi porodice Mendiluse, mnogi pisci objavljuju u izdavačakoj kući porodice Mendiluse El Cuarto Reich Argentino ${ }^{10}$. Irma Karasko je suparnica Danijeli de Montekristo, Segundo Hose Eredija piše o Francu Cvikauu), kao i u interakcije sa stvarnim ličnostima (Edelmira Tompson se druži sa Hitlerom, njena ćerka Lus se kao dete slikala sa Hitlerom, Ramires Hofman je blizak sa Pinočeom).

Eko skreće pažnju na referencijalnost i citatnost kao ključne odlike postmoderne književnosti. On navodi da u ovo doba „zaplet se takođe može naći u formi citiranja drugih zapleta, a citiranje može biti manje eskapističko od samog citiranog zapleta“11 (Eco, 1985: 65). Bolanjova Nacistička književnost u potpunosti odgovara ovom shvatanju savremene književnosti. Zaplet romana sačinjen je od više stotina podzapleta iz trideset biografija nacističkih pisaca podeljenih u trinaest poglavlja ${ }^{12}$, od njihovih dela i stvarnih biografija ličnosti sa kojima se imaginarni autori sreću u fikcionalnom svetu Roberta Bolanja. Mešajući stvarne i imaginarne ličnosti, Bolanjo oštro kritikuje celokupnu književnu scenu Latinske Amerike, poništavajući mogućnost razlikovanja nacista i nenacista, talentovanih i prosečnih pisaca (Schmukler, 2013: 118). Pored referencijalnosti, Bolanjo se obilato koristi i autoreferencijalnošću, što se najbolje vidi na primeru poslednje odrednice u knjizi, posvećene Karlosu Ramiresu Hofmanu. Isti lik postaje centralna figura narednog Bolanjovog romana Udaljena zvezda, gde se javlja pod mnogobrojnim pseudonimima ${ }^{13}$ (Karlos Vider,

8 Interesantne su očigledne aluzije na stvarne ličnosti, poput nemačkog arhitekte Huga Bosija, koji zapravo asocira na nacističkog dizajnera Huga Bosa; Valter Raus aluzija je na nacističkog oficira Valtera Raufa, koji je prebegao u Čile posle Drugog svetskog rata; urugvajski pisac Karlos Evija zove se isto kao kratkotrajni kubanski predsednik tridesetih godina XX veka (Bolaño, 2014: 531, 223, 278).

9 U epizodi o bitnicima i Džimu O’Benonu pominje se i putovanje u Jugoslaviju (Bolaño, 2014: 322).

$10 \mathrm{U}$ istom časopisu objavljuje i Karlos Vider u Udaljenoj zvezdi (Bolaño, 1999: 49).

11 "the plot could be found also in the form of quotation of other plots, and [...] the quotation could be less escapist than the plot quoted"

12 Pominje se preko devedest ličnosti ukupno, a biografske odrednice posvećene su piscima iz hispanoameričkih zemalja (Argentina, Kolumbija, Kuba, Čile, Peru, Meksiko, Venecuela, Gvatemala, Urugvaj), kao i iz Brazila, SAD-a i Haitija. Četrnaesto poglavlje naslovljeno "Epílogo para monstruos" donosi popis usput pomenutih imena, o čemu će biti više reči u nastavku rada.

13 Potraga za Hofmanom centralna je tema Udaljene zvezde. Na popisu na kraju Nacističke književnosti javljaju se ime Abela Romera, detektiva koji sa Bolanjom traga za Viderom, i još dvojice autora koji pišu i istražuju o Hofmanu, Vernera Mendesa Majera i Huana Eringa Lasa (Bolaño, 2014: 521, 536, 546). 
Alberto Ruis-Tagle, RP Ingliš, Žil Defo, Oktavio Paćeko, Huan Sauer). Što se tiče Ekovog eskapizma, Nacistička književnost je dokaz da svet koji Bolanjo kreira može biti sve samo ne eskapistički. U njemu stupaju na scenu svi oni prikriveni ili nedovoljno rasvetljeni fenomeni povezanosti umetnosti i diktature, koji su činili okosnicu latinoameričkih društava tokom celog XX veka.

Neupućeni čitaoci mogu shvatiti Bolanjovu knjigu kao autentičnu istoriju nacističke književnosti na američkom kontinentu, jer se nigde eksplicitno ne navodi da je ovo delo fikcija. Prema Eku, to ne bi bilo ništa pogrešno, jer u postmoderni „moguće je ne razumeti igru, ali je ipak shvatiti ozbiljno"14 (Eco, 1985: 68). Postmodernim književnim postupcima dovode se u pitanje temeljne kategorije: identitet, autor, autoritet ${ }^{15}$, fikcija, stvarnost. Upravo se u postmoderni prvi put uviđa simulativni karakter realnosti (Epštejn, 1998: 27), odnosno da je realnost „malo realna“ i da postoje i „nove realnosti“ (Lyotard, 1995: 17). Čitajući ovu istoriju književnosti, čitaoci zapravo prate fikcionalni roman i prepuštaju se igri zabluda i iluzija. To je roman koji „simulira i dosljedno iznevjerava leksikonsku formu“ (Ivankovac, 2017: 137).

Postmoderni tekstovi odbacuju sveznanje i sveprisutnost trećeg lica i umesto toga ulaze u dijalog između naratorovog glasa i zamišljenog čitaoca (Hačion, 1996: 27-28). U slučaju Nacističke književnosti, parodičnost je dvostruka. Čileanski pisac koristi objektivnu naučnu vrstu kao što je enciklopedija (leksikon) kroz koju odbacuje sveznanje i naučnu neutralnost oličenu u upotrebi trećeg lica jednine. On klasičan žanr isupnjava ironičnom sadržinom; služi se kanonizovanom formom kako bi predstavio nekanonizovanu sadržinu (Schmukler, 2013: 115; Ríos Baeza, 2014: 65). U završnom poglavlju o Ramiresu Hofmanu, javlja se sam pisac kao autodijegetički pripovedač, s tim što je njegovo prisustvo fickionalizovano u skladu sa celim romanom (Jennerjahn, 2002: 71). On je ujedno homodijegetički narator pod imenom Bolanjo jer je i sam uključen u radnju i predstavlja se kao svedok Ramires Hofmanovog umetničkog performansa ${ }^{16}$. Na taj način Bolanjo razbija sve kanone književnonaučnih vrsta i u duhu postmoderne igre prepliće pripovedne nivoe, izjednačavajući autora, pripovedača i književnog lika. On traži zajedničku podlogu za „istorijsko i književno pisanje“ (Hačion, 1996: 178) tako što piše književno delo istoriografskim sredstvima. Ovom pseudoistorijom književnosti, Bolanjo zapravo sledi princip koji objašnjava Hačion (1996: 29), prema kome parodija u postmoderni uključuje samu sebe i izaziva ono što parodira; $u$ ovom slučaju, normiranost književne kritike i istorije književnosti.

\section{Postmoderne tehnike Roberta Bolanja}

Bolanjo je stvarao pod uticajem Borhesa i Kortasara, začetnika hispanoameričke fantastike, pritom se oslobodivši nasleđa magičnog realizma (Dickov, 2016:

14 "it is possible not to understand the game and yet to take it seriously"

15 Kategorije autora i autoriteta dovedene su u pitanje time što se Bolanjo obraća kao istoričar književnosti sa različitih pripovedačkih pozicija, heterodijegetičke, homodijegetičke i autodijegetičke. Time se stvara utisak da je pripovedač naizgled naučnog dela nepouzdan, nestabilan i fragmentiran.

16 Hofmanova, odnosno Viderova vazdušna poezija puna je intertekstualnih referenci, naročito na Bibliju. Više o tome videti u Huber (2018). 
284). Njegova dela predstavljaju umetničku obradu burne latinoameričke stvarnosti sredstvima postmoderne.

Pisanje izmišljenih istorija književnosti poznato je u hispanoameričkoj književnosti mnogo pre Bolanja. Prvo hispanoameričko delo napisano takvim literarnim postupkom jeste Stvarni i izmišljeni portreti (Retratos reales e imaginarios, 1920) Alfonsa Rejesa. Usledila je Borhesova zbirka priča Univerzalna istorija beščašća (Historia universal de la infamia, 1935). Aluzija na ovu knjigu prisutna je u poslednjem poglavlju Nacističke književnosti naslovljenom "Ramírez Hoffman, el Infame" ${ }^{17}$. Još neki prethodnici Bolanjove tehnike jesu i Huan Rodolfo Vilkok (La sinagoga de los iconoclastas, 1972), Adolfo Bioj Kasares i Borhes (Crónicas de Bustos Domecq, 1975), Enrike Vila-Matas (Historia abreviada de la literatura portátil, 1985) (Crusat 2019; González Ángel 2018). Ipak, preteča svih ovih dela jeste zbirka priča Vies imaginaires (1896) francuskog pisca Marsela Švoba, koji je celokupnim radom bitno uticao na Bolanja (Crusat, 2019: 250; Huber, 2018: 55-56). Krusat (Crusat, 2019: 253) navodi da su neke od ključnih odlika svih hispanoameričkih izmišljenih biografija deformisanje stvarnosti, ironija i satira na aktuelne kulturne i književne teme, kao i preterana upotreba groteske. Sve ove odlike vidljive su u Bolanjovom romanu.

Gonsales Anhel (González Ángel, 2018: 164) ističe da Bolanjo intertekstualnost namerno dovodi do granice plagijata, pa i autoplagijata. Naime, čileanski pisac na početku Udaljene zvezde jasno navodi da je ovaj roman nastao na osnovu poslednjeg poglavlja Nacističke književnosti, koje je poslužilo kao skica iz koje su preuzeti čitavi pasusi (Bolanjo, 2004: 9). Ovakav postupak naziva se i transtekstualnost (Ríos Baeza, 2014: 68) i tipičan je za postmodernu. Odrednica o Ramiresu Hofmanu bitno se razlikuje od ostatka romana: po tonu, stilu, jeziku, složenijoj kompoziciji nalik na detektivski roman i većem broju likova. U tom smislu, zanimljivo je razmotriti i postmoderne pojmove hiperteksta i hipoteksta. Iako Nacistička književnost hronološki prethodi Udaljenoj zvezdi, Udaljena zvezda je hipertekst u odnosu na koji je Nacistička književnost hipotekst. Stariji tekst predstavlja nedovršeni početak priče o Ramiresu Hofmanu, koji postaje zaokružena celina u novijem hipertekstu. Ovde je očigledna upotreba postupka reiteracije, odnosno ponovne upotrebe postojećeg materijala uz rekontekstualizovanje. Ovakvu vrstu repetitivnosti Kalabreze (Calabrese, 1999: 44-45) smatra legitimnom estetikom XX veka, koja je umnogome prevazišla zahteve za originalnošću iz prethodnih epoha. Tehnika pomoću koje tekstovi nastaju kao proširena verzija prethodnih tekstova naziva se i fraktalnost (fractalidad) i podrazumeva upotrebu identičnih motiva i aspekata fabule u različitim delima (Echevarría, 2013: 448-449). Još jedan primer transtekstualnosti i intertekstualnosti u vezi sa romanom Nacistička književnost u Americi vidljiv je u romanu Udaljena zvezda. Bibijano, jedan od naratora, poziva se na antologiju koju je Bolanjo u stvarnosti već napisao, te se navodi: „na kraju je želeo da napiše knjigu, antologiju naci literatura dveju Amerika. Zamašnu knjigu, [...] koja bi pokrivala sve manifestacije

17 „Ramires Hofman, beščasni“. Podvlačenje je autorsko. Rivera-Soto (2018: 89) smatra da je ceo roman Nacistička književnost u Americi direktan dijalog sa Borhesovom prozom. 
naci literature na našem američkom kontinentu, od Kanade [...] do Čilea“18 (Bolanjo, 2004: 44). Kasnije se saznaje da je objavio knjigu El nuevo retorno de los brujos (Novi povratak veštaca) o južnoameričkim fašističkim književnim pokretima sedamdesetih i osamdesetih, gde pominje Karlosa Videra (Bolaño, 1999: 55).

Roman Nacistička književnost u Americi odudara od prave forme istorije književnosti po sledećim aspektima:

- ne postoji precizan naučno zasnovan kriterijum klasifikacije biografskih odrednica;

- kriterijumi grupisanja su raznoliki i variraju od poglavlja do poglavlja19 ${ }^{19}$ (porodični: "Los Mendiluce", "Los fabulosos hermanos Schiaffino"; tematski: "Los poetas malditos"; žanrovski: "Visión, ciencia-ficción”; etnički: "Dos alemanes en el fin del mundo"; geografski: "Poetas norteamericanos"; polni: “Letradas y viajeras");

- poglavlja su opisno naslovljena i proizvoljno uređena;

- odrednice se detaljno bave privatnim životom i uverenjima pisaca i uglavnom se završavaju poetskim ili apsurdnim opisima smrti i propasti (Da Sousa, Lus Mendiluse, Irma Karasko; Rori Long, Italo i Arhentino Skjafino).

Subjektivnim pristupom građi Bolanjo razara kategoriju naučne utemeljenosti. On pokazuje prezir prema bilo kakvom formalnom (npr. abecednom) ili estetskom kriterijumu klasifikacije (Schmukler, 2013: 12). Jedan od najočitijih primera simulirane faktografije $u$ romanu jesu godine rođenja i smrti i objavljivanja knjiga pojedinih pisaca. Naime, Bolanjo je roman napisao 1996. godine, a naveo je da su neki autori umrli 2004, 2016, 2021, 2029, 2040. godine itd. Ovaj postupak ima dvojaku funkciju: čisto fikcionalnu i ideološku. Posmatrano kroz prizmu fikcije, Bolanjo je vremenski izmestio svoje likove kako bi pokazao da je u fikcionalnoj stvarnosti moguće nadživeti svog književnog tvorca. Gledano ideološki, autor oštro kritikuje stalno prisustvo nacističkih elemenata u lationameričkoj javnosti, sluteći tako da će oni biti aktuelni i duboko u XXI veku. Ovakvo brisanje granica između istorijske stvarnosti i fikcije tipično je za postmodernu.

Nacistička književnost odgovara žanru istorije književnosti po sledećim kriterijumima:

- prisutan je kritički aparat (epilog, anotiran indeks imena, izdavača, časopisa i mesta okupljanja pisaca);

- uključen je abecedni spisak citiranih i pomenutih knjiga;

- odrednice počinju standardnim biografskim podacima: puno ime i prezime i eventualni pseudonimi autora, mesto i godina rođenja i smrti;

- iznosi se faktografija, analiza dela i vrednosni sudovi o književnim postignućima pisaca.

Nacistička književnost u Americi predstavlja „ludičko rasklapanje onoga što je u modernizmu bilo svetinja“20 (Rivera-Soto, 2017: 100). Tako se dovode u pitanje

18 "quería, finalmente, escribir un libro, una antología de la literatura nazi americana. Un libro magno, [...] que cubriría todas las manifestaciones de la literatura nazi en nuestro continente, desde Canadá [...] hasta Chile" (Bolaño, 1999: 25).

19 Dva autora dobijaju zasebna poglavlja: Maks Mirabel i Karlos Ramires Hofman.

20 "un desmontaje lúdico de aquello que en la modernidad fueran ideas sagradas" 
subjekat, poimanje istorije, kao i značaj nauke. U postmoderni postaje dozvoljeno kombinovati nauku i umetnost, znanje i igru.

Po Kalabrezeovoj terminologiji (Calabrese 1999), postmoderna se može okarakterisati kao neobarokno doba, u kom dolaze do izražaja tehnike poput akumulacije, kićenja, prekomerne upotrebe detalja i hiperbole. Čitava Nacistička književnost počiva na nizanju nepotrebnih i nerelevantnih detalja iz života nacističkih pisaca, čime se dodatno potcrtava besmisao i jalovost njihovog umetničkog delovanja. Ovakvom tehnikom Bolanjo se namerno udaljava od naučnog stila pisanja jer ne poštuje kriterijume selekcije i relevantnosti izloženih informacija.

Rivera-Soto (2017: 106) smatra da je jezik dela Nacistička književnost aluzija na intertekstualni jezik naučnih istraživanja, kojim se iskazuje erudicija i daju se kritički sudovi o delima. Bolanjo ironizira učenost, književne žanrove i narativne tehnike (Rivera-Soto, 2017: 108). Njegova pozivanja na druge izvore ili svedočenja savremenika takođe su plod književne mašte i predstavljaju pseudocitate, te se može tvrditi da je Bolanjo u potpunosti prihvatio načelo postmoderne igre. Stoga ne čudi da Jergović (2015) naziva ovo delo „roman-igra“, a Ivankovac (2017: 137) „romaneskni ludizam“. Jedan zanimljiv primer pseudocitata jeste pozivanje na nepostojeću knjigu Diccionario de Autores Cubanos (čak je navedena i godina izdanja, 1978), koja navodno ne pominje Kabreru Infantea, ali daje prostor imaginarnom autoru Ernestu Peresu Masonu (Bolaño, 2014: 145). Ovakvom pseudodokumentarnom igrom Bolanjo suptilno iznosi sud o književnoj panorami Kube pod Kastrom, gde su mnogi pisci, poput Kabrere Infantea, lako iz milosti padali u nemilost režima, dobijali prostor za stvaranje, a potom ostajali bez ikakvih prava i bivali progonjeni. Zastupljena su i mnogobrojna pozivanja na izmišljene ili neimenovane biografe, kritičare, antologije i istorije književnosti.

Kao i mnoga druga postmoderna književna dela, Nacistička književnost u Americi zasniva se na tehnici palimpsesta. U pitanju je tehnika pisanja i tumačenja književnosti koja podrazumeva da se u okviru dela prepoznaju delimično skriveni različiti slojevi prethodnog književnog nasleđa, koje je u određenoj meri inspirisalo pisanje ili uticalo na tvorca postmodernog dela. Bolanjov celokupni opus može se analizirati kao „totalni palimpsest“ (Candia Cáceres 2005; Hasan 1983) u kom su likovi, motivi i elementi radnje višestruko isprepleteni. Ova tehnika otvara mogućnost upotrebe pseudocitata i pseudodokumentarnih izvora, pomoću kojih se stvara iluzija verodostojnosti.

Opisujući rad fiktivnog pisca Zaka Zodenšterna na romanu El Control de los Mapas, Bolanjo kao da opisuje sopstveni stvaralački proces: roman je pun apendiksa, mapa, imena, ima interaktivne i multimedijalne odlike, nema glavnog lika i napisan je u fragmentima. Ovakav postupak dekonstrukcije vidljiv je u Nacističkoj književnosti. S druge strane, Bolanjo kritikuje pravo plagijatorstvo Haićanina Maksa Mirabela koji ,je postao stručnjak u veštini usitnjavanja pesme sve dok je ne prisvoji“21 (Bolaño, 2014: 300). Mirabel preuzima pesme drugih nefikcionalnih pesnika iz celog sveta (Rene Depestr, Entoni Felps, Leopold-Sedar Sengor) i stvara nekoliko alter ego 
ličnosti (Maks Kazimir, Maks fon Hauptman). Svaki alter ego zastupa drugačije ideološko stanovište: Fon Hauptman je zagriženi nacista, Le Gel je pragmatični militarista, Mirabel je lirski nastrojen patriota oduševljen francuskom kulturom, a Kazimir je poštovalac crnačke kulture. Bolanjo kroz lik Mirabela revidira pitanje višekomponentnog (latino)američkog identiteta i suživota različitih kultura i kulturnih uticaja na ovom podneblju. Mirabel je oličenje mnogih stanovnika Latinske Amerike, $u$ kojima su pomešane krvi i stavovi predaka različitih rasa, naroda i pogleda na svet. Ta mešavina predstavlja veliko blago i posebnost ovog područja, ali i izvor trauma, nesporazuma i viševekovnih konflikata. Bolanjo osvetljava ovu unutrašnju podeljenost stanovnika Latinske Amerike, koji čuvaju svoje mnogobrojne identitete, ali ih i skrivaju i beže od njih.

I pored kritika na račun nedostatka autentičnog talenta kod Mirabela, Bolanjo kroz ovakve slike otvara pitanje same teorije postmoderne: koja je razlika između plagijata i postmodernog postupka intertekstualnosti i palimpsesta i gde su granice autorstva? Bolanjov postupak u ovom romanu sličan je Mirabelovim tehnikama i Mirabelu se delimično odaje priznanje za neku vrstu kreativnosti u plagijatorstvu. Celokupno Bolanjovo stvaralaštvo, pa i ovaj roman, pokazuju da intertekstualnost i čitanje književnosti sopstvenih prethodnika mogu biti temelj za novo, originalno delo. Autor nije samo onaj koji je prvi izneo neku ideju, već i onaj ko ju je prepoznao kao vrednu i univerzalnu i udahnuo joj novi život pomoću novih formi i u novim kontekstima. U Nacističkoj književnosti tako dolazi do temeljnog preispitivanja kategorija identiteta, fikcije i autora.

Pored dominantnih tema književnosti i politike, u Nacističkoj književnosti u Americi prisutne su teme iz popularne kulture, poput fudbala ${ }^{22}$, plesa, televizije, filma i pornografije, što je takođe odlika postmoderne. Intermedijalnost i uticaj različitih medija na umetničku praksu karakteristični su za prozu sa kraja XX veka, pa tako i za stvaralaštvo Bolanjovih likova u Nacističkoj književnosti. Bolanjo namerno parodira izopačenost nacisitičkih pisaca, pa tako govoreći o Silviju Salvatiku nabraja njegove rasističko-fašističke stavove, da bi nakon toga izneo bezazleni svakodnevni detalj: „Bio je fudbaler i futurista“23 (Bolaño, 2014: 117).

\section{Odnos istorije i fikcije u Nacističkoj književnosti u Americi}

Šmukler (Schmukler, 2013: 114) navodi da se epoha u kojoj Bolanjo stvara odlikuje „jasnim ideološkim stavom prema književnoj istoriji i samoj istoriji“24. Upravo je to odnos postmoderne poetike prema istoriji, na kom insistira Linda Hačion (1996: 296), tvrdeći da je ideološko neodvojivo od estetskog. Slično tvrdi i Liotar (Lyotard, 1995: 10), pozivajući se na Albrehta Velmera, i navodi da se u postmoderni estetičko iskustvo upotrebljava za istraživanje istorijske situacije života.

Pod terminom nacizam, Bolanjov roman Nacistička književnost u Americi obuhvata mnoge ideologije: fašizam, frankizam, peronizam, rasizam, antisemitizam,

22 Celokupno književno stvaralaštvo i javni angažman fikcionalne braće Skjafino obeleženo je opsednutošću fudbalom i klubom Boka Juniors, za čije neuspehe krive Jevreje (Bolaño, 2014: 362-363).

23 "Fue jugador de fútbol y futurista".

24 "[por] una clara posición ideológica con respecto a la historia literaria y a la historia sin más" 
učenje o arijevskoj rasi, eugeniku, imperijalizam, kolonijalizam, ksenofobiju, homofobiju, verski fanatizam i generalno sve ultradesničarske pokrete i ideološka stanovišta. Mnogi pisci u romanu ujedno su političari i funkcioneri (Huan Mendiluse Tompson je ambasador u Španiji i član Peronove vlade, Irma Karasko je istaknuta frankistkinja, Maks Mirabel je ataše za kulturu u Bonu).

Nacistička književnost zauzima kritički stav prema piscima fašističke orijentacije i suptilno izvrgava ruglu njihovo delovanje tako što ga pokazuje kao društveno opasno, ali umetnički bezvredno i beznačajno. U pitanju su marginalizovani, mahom obrazovani ${ }^{25}$ pisci, koji avangardi daju desničarski predznak, čine je destruktivnom i bliskom latinoameričkim diktaturama i tako utiču i na političku i na umetničku propast (Crusat, 2019: 257; Donoso, 2007: 5; Luche, 2014: 343).

Istoriografska dimenzija već na početku poprima ludički karakter (Schmukler, 2013: 115) time što se kao epigraf navodi parodična referenca na honduraškog pisca kratkih priča Augusta Monterosa na Heraklitov citat panta rhei: „Kada je reka spora i raspolaže se dobrim biciklom ili konjem, moguće je okupati se dvaput (pa i triput, u zavisnosti od higijenskih potreba) $u$ istoj reci“26 (Bolaño, 2014: 7). Upotreba ovakvog citata probija horizont očekivanja čitalaca prema istorijama književnosti, te se uspostavlja ironična i humoristična dimenzija celog dela. Indikativno je što je Bolanjo odabrao baš Monterosov iskaz za citiranje. Kao što Monterosove kratke priče stvaraju efekat začudnosti, tako i odrednice u Nacističkoj književnosti, uz mnogobrojne detalje i neobarokna kićenja, provokativno deluju na čitaoce. Ironično-humoristična dimenzija produžava se sve do „Epiloga za čudovišta“, gde su date kratke, groteskne i degutantne zabeleške o svim ličnostima pomenutim u romanu. Roman obiluje „čudovišnim“ opisima, od kojih izdvajamo nekoliko: „počeo je kao staljinista, a završio kao salinista“; „mešavina pacova i pauna, kažu drugi“; „njegov polni organ, u erekciji, imao je tačno 30 cm“; „plačući i serući u gaće“; „izmišljotina Ernesta Peresa Masona?“; „drugi kažu, cinični kurvin sin“27 (Bolaño, 2014: 503, 507, 509, 510, 514, 522).

Sama ideja pisanja jedne antinaučne istorije književnosti predstavlja subverziju. Tako se otvara mogućnost kritike svih aspekata književne scene i preispitivanje književne tradicije. Krusat (Crusat, 2019: 248) navodi da se upravo u hispanoameričkoj postmoderni uspostavlja ideja da „sadašnjost može izmeniti istu tu tradiciju kada je preoblikuje“ ${ }^{28}$. U tom smislu, istorija književnosti takođe može biti objekat stvaranja umetnosti (Crusat, 2019: 249). Sam Bolanjo je rekao da u romanu Nacistička književnost govori „o bedi i suverenosti književne prakse“ (Bolanjo, 2017: 61).

Jedan od primera gde je Bolanjova parodija dostigla vrhunac jeste opis stvaralačkog procesa Argentinke Edelmire Tompson de Mendiluse. Narator do besmislenih detalja opisuje kako je autorka uredila svoj dom po uzoru na delo Edgara Alana

25 Postoje i suprotni slučajevi. Brazilac Luis Fonten da Sousa piše pobijanje Hegelovog filozofskog sistema, a zapravo meša njegovo i Kantovo učenje (Bolaño, 2014: 122-123).

26 "Cuando el río es lento y se cuenta con una buena bicicleta o caballo sí es posible bańarse dos (y hasta tres, de acuerdo con las necesidades higiénicas de cada quien) veces en el mismo río".

27 "empezó como estalinista y terminó como salinista", "mezcla de rata y pavo, según otros", "su miembro viril, erecto, medía exactamente $30 \mathrm{~cm}$ ", "llorando y cagándose en los pantalones", "¿un invento de Ernesto Pérez Masón?", "según otros, un cínico hijo de puta”.

28 "el presente puede alterar esa misma tradición al recrearla" 
Poa Filozofija nameštaja kako bi se nadahnula za pisanje dela La Habitación de Poe (Poova soba), koje veoma liči na Poov original. Edelmira Tompson tako oličava neku vrstu bezuspešnog borhesovskog Pjera Menara, očaranog Hitlerom i u suparništvu sa Evom Peron. Zatim, stvaralaštvo Amerikanca Harija Sibelijusa ulazi u polemiku i poredi se sa spisima sociologa Arnolda Tojnbija. Sibelijus radi isto što i Bolanjo: kombinuje fikciju i stvarnost. Likovi njegovih knjiga su Hemingvejev Robert Džordan, Diznijev Bambi, Kapoteova Holi Golajtli, Skarlet O’Hara i Ret Batler, kao i junaci Gertrude Stajn, Džona Dos Pasosa, Kurta Vonegata, Skota Ficdžeralda. Bolanjo o Sibelijusu kaže: „njegovi likovi, pozajmljeni ili ne, njegove priče, pozajmljene ili ne, da, dosežu, najviše pripovedačke domete“29 (Bolaño, 2014: 292).

Rodriges Freire (Rodríguez Freire, 2013: 66) govoreći o odnosu Bolanjove fikcije prema stvarnosti navodi da „nije relevantno kada se tekst poklapa sa stvarnošću ili razlikuje od nje, već način na koji ga čitamo, način na koji je Bolanjo uspeo da nas

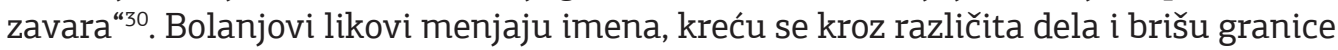
između stvarnosti i fikcije, pomerajući time i granice identiteta i književne i vanknjiževne stvarnosti (Fischer, 2013: 150). Ivankovac (2017: 138) navodi da je glavni lik romana Nacistička književnost zapravo - tema - odnosno sama književnost o kojoj autor piše.

Martin-Estudiljo i Bage Kiles (Martín-Estudillo/Bagué Quílez, 2013: 480) vide Bolanja kao predstavnika savremene hispanske hibridne književnosti, čiji je jedan od glavnih aspekata „briga za priče koje osciliraju između ponovnog čitanja zvanič-

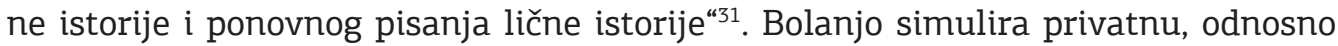
personalnu istoriju nacističkih pisaca, iznoseći mnoštvo biografskih anegdota, kojima baca drugačije svetlo na zvaničnu latinoameričku istoriju i istoriju književnosti. Reinterpretacija istorije, u terminologiji Linde Hačion, jedan je od osnovnih ciljeva postmoderne, pa i Bolanjove umetnosti. Bolanjo istoriju reinterpretira tako što je dovodi u tesnu vezu sa književnošću i umetnošću i pokazuje da književnost ne nastaje samo iz istorije, već $i$ istorija nastaje iz književnosti. Književnost je za Bolanja polje neodvojivo od istorije, koje doprinosi suštinskom razumevanju istorijskih $i$ ideoloških mehanizama.

\section{Zaključak}

Sa stanovišta književne teorije, Bolanjo koristi tipične postmoderne postupke kako bi stvorio originalnu fuziju književnih i istorijsko-političkih tema. Najviše se služi intertekstualnošću, referencijalnošću, parodijom, ironijom, dekonstrukcijom, fragmentarnošću i ideološkom obojenošću. Koristi istoriografske tehnike, odnosno tehnike istorije književnosti, kako bi stvorio imaginarnu verziju sveta književnika ultradesničara. Bolanjo se, poznajući postmoderne tendencije, odlučio da formu čija

29 “[...] sus personajes, prestados o no, [...] sus historias, prestadas o no, [...] alcanza[n], entonces sí, las más altas cotas narrativas"

30 "lo [...] relevante no es cuándo el texto coincide con, o se diferencia de, la realidad, sino la forma en que lo leemos, la forma en que Bolańo ha logrado atraparnos"

31 "la preocupación por las ficciones que oscilan entre la relectura de la historia oficial y la reescritura de la historia privada” 
je svrha tumačenje književnosti iskoristi u svrhe predstavljanja jednog izmišljenog sveta. Tako u duhu postmoderne koristi postmoderno književno-naučno sredstvo čineći ga još „dodatno“ postmodernim, dajući mu fikcionalnu dimenziju. Njegova dela predstavljaju umetničku obradu burne latinoameričke stvarnosti sredstvima postmoderne. Udaljavanjem od realnosti pomoću postmodernih tehnika, Bolanjo se zapravo približava suštinskim društveno-istorijskim problemima Latinske Amerike i njihovu zastrašujuću dimenziju dodatno ističe sredstvima postmoderne.

Nacistička književnost u Americi Roberta Bolanja može se opisati kao „dekonstrukcija prosvećenog znanja“32 (Rivera-Soto, 2017: 112). Bolanjov stil u ovoj pseudoistoriji književnosti varira od naučničkog, gotovo telegrafski sažetog, do poetski nadahnutog i sentimentalnog. Ovakva mešavina registara i pripovedačkih perspektiva tipična je za postmodernu prozu. Ovim romanom Bolanjo briše granice između istorijske stvarnosti i fikcije i pokazuje da, kao što fikcija nastaje iz stvarnosti, tako i stvarnost može nastati iz fikcije.

Ovaj temeljni pregled upotrebe postmodernih postupaka i odnosa istorije i fikcije u romanu Nacistička književnost u Americi Roberta Bolanja svakako nije potpuno iscrpan. Suština Bolanjove postmoderne tehnike najbolje se sagledava u svetlu njegovog celokupnog opusa, u kome se određene teme, motivi i stilski postupci višestruko ponavljaju. Ovaj roman je jedan od najindikatvnijih za takvu analizu jer je u njemu Bolanjo otišao najdalje u poigravanju formom, istorijom i umetnošću.

Napomena: Rad je nastao u okviru naučnoistraživačkog rada na Filološkom fakultetu Univerziteta u Beogradu, gde je autorka angažovana kao stipendistkinja Ministarstva prosvete, nauke i tehnološkog razvoja Republike Srbije.

\section{Literatura}

Barth, J. (1984). The Literature of Replenishment: Postmodernist Fiction. In J. Barth, The Friday Book: Essays and Other Non-Fiction (pp. 193-206). London: The John Hopkins University Press.

Bolanjo, R. (2017). O sebi (I. Marojević, prev.). Polja, 504, 61.

Calabrese, O. (1999). La era neobarroca (A. Giordano, Trans.). Madrid: Cátedra.

Candia Cáceres, A. (2005). Tres: Arturo Belano, Santa Teresa y Sión. Palimpsesto total en

la obra de Roberto Bolaño. Espéculo: Revista de Estudios Literarios, 31, 1-11.

Crusat, C. (2019). La tradición hispanoamericana de la "vida imaginaria": una antología inminente desde Alfonso Reyes a Roberto Bolaño (y un decadente francés). Taller de Letras, 64, 247-262.

Donoso, Á. (2007). Depurar la poesía de la poesía misma: poesía, política y muerte en Estrella distante de Roberto Bolaño. Working Papers in Romance Languages, 1, 1-12. Echevarría, I. (2013). Bolaño extraterritorial. In E. Paz Soldán \& G. Faverón Patriau (Eds.), Bolaño salvaje (pp. 447-461). Barcelona: Candaya.

Eco, U. (1985). Postmodernism, Irony, the Enjoyable. In U. Eco, Reflections on "The Name of the Rose" (W. Weaver, Trans.) (pp. 65-72). London: Secker \& Warburg.

32 "deconstrucción del saber ilustrado" 
Fischer, M. L. (2013). La memoria de las historias en Estrella distante de Roberto Bolaño. In E. Paz Soldán \& G. Faverón Patriau (Eds.), Bolaño salvaje (pp. 142-159). Barcelona: Candaya.

González Ángel, S. (2018). De escritores portátiles y bárbaros: Vila-Matas y Bolaño escribiendo historias de la literatura inventadas. Pasavento Revista de Estudios Hispánicos, 6, 153-166.

Hačion, L. (1996). Poetika postmodernizma: istorija, teorija, fikcija (V. Gvozden i Lj. Stanković, prev.). Novi Sad: Svetovi.

Huber, A. (2018). Arte, violencia y política: la tríada principal en las novelas Estrella distante y Amuleto de Roberto Bolaño. In I Actas de la Escuela internacional de verano de estudios latinoamericanos (pp. 52-64). Belgrado: Asociación de Hispanistas (SERBIA). http://letnjaskola.drustvohispanista.rs/wp-content/ uploads/2018/06/I-ACTAS-DE-LA-ESCUELA-INTERNACIONAL-DE-VERANO-DEESTUDIOS-LATINOAMERICANOS_v4.pdf

Ivankovac, D. (2017). Tradicija romanesknog ludizma i radikalnog (pre)oblikovanja forme. Polja, 504, 137-140.

Jennerjahn, I. (2002). Escritos en los cielos y fotografías del infierno. Las "acciones de arte" de Carlos Ramírez Hoffman, según Roberto Bolaño. Revista de crítica literaria latioamericana, 56, 69-86.

Jergović, M. (2015). Roberto Bolaño: Naci-pisci. Subotnja matineja. https://www.jergovic. com/subotnja-matineja/roberto-bolano-naci-pisci/

Luche, L. (2014). La imagen de las vanguardias en La literatura nazi en América de Roberto Bolaño. Boletín Millares Carlo, 30, 342-349.

Lyotard, J. F. (1995). Šta je postmoderna? (K. Jančin, prev.). Beograd: Art Press.

Martín-Estudillo, L., Bagué Quílez, L. (2013). Hacia la literatura híbrida: Roberto Bolaño y la narrativa española contemporánea. In E. Paz Soldán \& G. Faverón Patriau (Eds.), Bolaño salvaje (pp. 462-486). Barcelona: Candaya.

Ríos Baeza, F. A. (2014). Wieder, wider, weiden: casos de parodia y autoparodia en la narrativa de Roberto Bolańo. Valenciana, 14, 59-87.

Rivera-Soto, J. (2017). ¡Muerte a Voltaire! El crepúsculo de los ilustrados en La literatura nazi en América de Roberto Bolaño. Rev. Let. São Paulo, 57, 99-117.

Rivera-Soto, J. (2018). Pliegues, repliegues y despliegues textuales técnicas posmodernas en la narrativa de Roberto Bolaño. Rev. Let. São Paulo, 58, 77-95.

Rodríguez Freire, R. (2013). Bolaño, Chile y la desacralización de la literatura. Guaraguao, 44, 63-74.

Sánchez Carbó, J. (2011). Repetición y parodia en La literatura nazi en América, de Roberto Bolaño. Ibero Puebla, 141-146. http://hdl.handle.net/20.500.11777/4085

Schmukler, E. (2013). Abrir la historia: Roberto Bolaño, el "principio atlas" y los modos ficcionales de re-presentar la historia literaria. Mitologías Hoy, 7, 113-123.

Дицков, В. (2016). Хиспаноамеричка књижевност: од постмодернизма до постбума. Београд: Филолошки факултет.

[Dickov, V. (2016). Hispanoamerička književnost: od postmodernizma do postbuma. Beograd: Filološki fakultet] 
Епштејн, М. (1998). Постмодернизам (Р. Мечанин, прев.). Београд: Zepter book world. [Epštejn, M. (1998). Postmodernizam (R. Mečanin, prev.). Beograd: Zepter book world] Хасан, И. (1983). Приступ појму постмодернизма (З. Циана, прев.). У Антологија Поља (стр. 16-18). Нови Сад: Поља.

[Hasan, I. (1983). Pristup pojmu postmodernizma (Z. Ciana, prev.). U Antologija Polja (str. 16-18). Novi Sad: Polja]

Џенкс, Ч. (2016). Шта је постмодернизам? (М. Протић, прев.). Лозница: Карпос.

[Dženks, Č. (2016). Šta je postmodernizam? (M. Protić, prev.). Loznica: Karpos]

\section{Izvori}

Bolaño, R. (1999). Estrella distante. Barcelona: Anagrama.

Bolaño, R. (2014). La literatura nazi en América. Epub libre. https://emakbakea.files. wordpress.com/2017/10/la-literatura-nazi-en-amc3a9rica.pdf

Bolanjo, R. (2004). Udaljena zvezda (I. Marojević, prev.). Novi Sad: Svetovi.

\section{Ana Z. Huber}

\section{Summary}

\section{POSTMODERN LITERARY DEVICES, HISTORY AND FICTION IN THE NOVEL NAZI LITERATURE IN THE AMERICAS BY ROBERTO BOLAÑO}

The topic of this paper is the employment of postmodern literary devices in the novel Nazi Literature in the Americas (1996) by the Chilean writer Roberto Bolaño, as well as the relation between history and fiction in this novel. Considering the main principles of postmodern literature defined by John Barth, Charles Jencks, Umberto Eco and Jean-François Lyotard and using the inductive and deductive method, we will study to what extent Bolaño's novel belongs to the postmodern poetics formally and thematically. We will focus on the particular postmodern devices in the novel, such as subjectivity, intertextuality, referentiality, ideology, technique of palimpsest, irony, parody, deconstruction, fragmentarism and repetitiveness. We will intend to explain, through the examples from the novel, why the process of writing in this novel is fundamentally postmodern. We will take into consideration Linda Hutcehon's formulation of postmodern poetics, especially the question of the relation between historical and fictional dimension in the postmodern literature that revalorizes fixed categories like identity, author, knowledge, fiction and reality. We will prove that the fusion of historical reality and fiction represents the essence of Bolaño's postmodern poetics, which is implemented in order to erase the borders between history and fiction. Bolaño plays with history, literature and literary studies. He apparently distances himself from reality, but in fact points to fundamental social and historical problems of Latin America.

\section{Key words:}

Nazi Literature in the Americas, Roberto Bolaño, postmodernism, history, fiction 